\title{
POLITIK HUKUM NASIONAL LEGISLASI HUKUM EKONOMI SYARIAH
}

\author{
M. Rifqinizamy Karsayuda \\ Fakultas Hukum Universitas Lambung Mangkurat Banjarmasin \\ rifqi.karsayuda@gmail.com
}

\begin{abstract}
Abstrak
National political law on the existence of sharia economic in Indonesia can be seen through two general aspects, namely institutional aspect and legal aspect that born from the substance of law in the legislation. In the institutional aspect, the absolute authority of Religious Court in solving any sharia economic disputes, the existence of National Sharia Board (DSN), and the recognition of Sharia Arbitration (Basyarnas) are acknowledging the existence of sharia economic in Indonesia. Moreover, In the regulation aspect, sharia economic stated in various acts; such as Act 21/ 2008 about Islamic Banking, Act 19/2008 about Sharia Securities, Act 23/2011 on Zakat Management, and Act 50/2009 on the Religious Courts, Act 41/2004 on Waqf and others.

Politik hukum nasional terhadap keberadaan ekonomi syariah di Indonesia, dapat kita lihat melalui dua aspek, yaitu aspek kelembagaan dan aspek substansi hukum yang tercermin dari lahirnya peraturan perundang-undangan. Dari aspek kelembagaan dapat kita lihat salah satunya dalam kewenangan pada Peradilan Agama, dimana sengketa ekonomi syariah menjadi kewenangan mutlak Peradilan Agama, disamping diakuinya keberadaan Dewan Syariah Nasional (DSN) dan Badan Arbitrase Syariah (Basyarnas) yang kedudukannya berada di bawah Majelis Ulama Indonesia. Dari aspek peraturan perundang-undangan, dapat kita lihat dalam UU No.21 Tahun 2008 tentang Perbankan Syariah, UU Nomor 19 Tahun 2008 tentang Surat Berharga Syariah, UU 23 Tahun 2011 tentang Pengelolaan Zakat, dan UU Nomor 50 Tahun 2009 tentang Peradilan Agama, UU 41 Tahun 2004 tentang Wakaf serta yang lain-lainnya.
\end{abstract}

Kata Kunci: Politik, legislasi, ekonomi syariah

Soerjono Soekanto dan Purnadi Purbacaraka mengemukakan, disiplin PolitikHukum terbentuk dari gabungan dua disiplin hukum, yaitu disiplin ilmu hukum dan filsafat hukum. Ilmu Hukum diarahkan pada cara untuk mencapai tujuan. Adapun filsafat hukum diarahkan untuk melihat tujuan yang diinginkan. Proses interplay antara cara untuk mencapai tujuan dan melihat tujuan yang diinginkan itulah yang kemudian melahirkan politik hukum, dengan catatan bahwa politik dipahami sebagai policy, bukan dalam pengertian cara untuk memperoleh kekuasaan. Dalam hal ini yang dimaksud adalah kebijakan hukum (legal policy).

Dengan Kerangka pikir seperti ini, Purnadi Purbacaraka ${ }^{1}$ mengemukakan bahwa politik hukum dalam disiplin hukum bergerak pada tataran etik dan teknik kegiatan pembentukan hukum dan penemuan hukum. Lebih lanjut dijelaskan bahwa: Politik Hukum berbicara

${ }^{1}$ Imam Syaukani dan A. Ahsin Thohari, Dasar-Dasar Politik Hukum, Cet ke-8, (Jakarta: Rajawali Pres, 2012), h. 40 . 
pada tataran empiris fungsional dengan menggunakan metode teleologis-konstruktif, artinya bahwa politik hukum dalam pengetian etik dan teknik kegiatan pembentukan hukum dan penemuan hukum, lebih diarahkan untuk melihat sejauh mana hukum yang dibentuk memiliki nilai guna dan gerak dalam proses transformasi masyarakat yang diinginkan, proses yang melibatkan unsur-unsur yang mendukung terjadinya proses tersebut harus diperhatikan, termasuk dalam hal ini adalah pengaruh ideologi atau ajaran-ajaran politik kendatipun kecil pengaruh tersebut.

Sebagai sebuah disiplin hukum, politik hukum memberikan landasan akademis terhadap proses pembentukan dan penemuan hukum yang lebih sesuai dengan konteks kesejarahan, situasi dan kondisi, kultur, nilai-nilai yang berkembang dimasyarakat, dan dengan memperhatikan pula kebutuhan masyarakat terhadap hukum itu sendiri. Melalui proses seperti ini diharapkan produk hukum yang akan diimplementasikan ditengah-tengah masyarakat dapat diterima, dilaksanakan dan dipatuhi.

Pengertian Politik Hukum dapat dibagi dalam pengertian dari perspektif etimologi dan perspektif terminologi. Dalam perspektif etimologi politik hukum merupakan terjemahan bahasa Belanda "recht politik" yang berarti kebijakan (policy) sehingga dapat dikatan sebagai kebijakan hukum. Berkaitan dengan pengertian tersebut Klan menjelaskan bahwa kebijakan itu adalah tindakan secara sadar dan sistimatis, dengan mempergunakan saranasarana yang cocok, dengan tujuan politik yang jelas sebagai sasaran yang dijalankan langkah demi langkah. ${ }^{2}$

Menurut Bachsan Mustafa, Politik Hukum mengandung dua pengertian yaitu "Politik dan Hukum. Politik adalah aspek dari semua perbuatan yang berkenaan dengan usaha kolektif bagi tujuan-tujuan kolektif. Politik adalah tindakan yang dijalankan menurut suatu rencana tertentu, terorganisir dan terarah, yang secara tekun berusaha menghasilkan,

${ }^{2}$ Klan dalam Imam Syaukani dan A. Ahsin Thohari, Dasar-Dasar Politik..., h. 22. mempertahankan atau mengubah susunan kemasyarakatan.

Sementara itu Mahfud MD mengemukakan "Politik Hukum adalah legal policy atau garis (kebijakan) resmi tentang hukum yang akan diberlakukan baik dengan pembuatan hukum baru maupun dengan penggantian hukum lama, dalam rangka mencapai tujuan negara". ${ }^{3}$ Dengan demikian, politik hukum merupakan pilihan tentang hukum-hukum yang akan diberlakukan sekaligus pilihan tentang hukum-hukum yang akan dicabut atau tidak diberlakukan yang kesemuanya dimaksudkan untuk mencapai tujuan negara seperti yang tercantum di dalam pembukaan UUD 1945.

Mengenai hubungan antara hukum dan politik, Michael D. Bayles melihat hubungan politik dan hukum itu dari tiga pola interaksi yang terbangun di antara keduanya. ${ }^{4}$ Pola pertama, yang disebutnya sebagai pola empiris yaitu pola di mana politik mempunyai pengaruh yang sangat besar di dalam proses pembentukan konstitusi. Di sini dapat dikatakan bahwa politik membentuk hukum. Pola yang kedua adalah pola hubungan yang bersifat analitis, yaitu pola yang menggambarkan hukum membutuhkan kekuasaan politik agar dapat berlaku efektif. Pola ini meski diakui oleh Hans Kelsen, namun ia menolak adanya kebergantungan hukum terhadap politik dengan alasan efektivitas tersebut. Kelsen berpendapat bahwa meskipun banyak kalangan yang berpendapat adanya korelasi antara kekuasaan dan efektivitas hukum, menurut teori yang dibangunnya, hukum merupakan tatanan atau organisasi kekuasaan yang bersifat khas atau spesifik. ${ }^{5}$ Pola yang ketiga adalah pola hubungan yang bersifat normatif. Di dalam pola ini, politik

${ }^{3}$ Moh. Mahfud MD, Politik Hukum di Indonesia, cet ke-3, (Jakarta: Rajawali Press, 2010), h. 1.

${ }^{4}$ Michael Bayles, Law and Politics, http://www. bibliojuridica.org/libros/3/1014/14.pdf, diakses tanggal 16 Mei 2013, h. 137.

${ }^{5}$ Hans Kelsen, Teori Umum tentang Hukum dan Negara [General Theory of Law and State] Terjemahan oleh Raisul Muttaqien, Cetakan Pertama (Bandung:Nusa Media,2006), h.175 
harus menyediakan kekuatan normatif bagi berlakunya hukum.

Penegasan hubungan politik dan hukum ini perlu dilakukan agar dapat dipahami di bagian mana saja politik dapat berjalin dengan hukum dan di bagian mana saja politik memang harus berpisah dari hukum. Tidak adanya penegasan hubungan politik dan hukum berpretensi melahirkan pemahaman yang menempatkan hukum dalam posisi yang tidak suprematif. Kecenderungan itu ditangkap oleh Mahfud MD, ketika menghadapi pertanyaanpertanyaan yang diajukan oleh mahasiswa hukum seputar ketidakberdayaan hukum di hadapan politik. ${ }^{6}$

Jawaban atas problematika tersebut tidak dapat disederhanakan dengan mengidentifikasi politik dalam wujud law in action atau dengan memutus keterkaitan antara politik dengan hukum. Perubahan di bidang-bidang nonhukum, seperti politik, ekonomi, sosial, dan budaya, baik secara langsung maupun tidak langsung memberikan pengaruh yang signifikan terhadap hukum. Menghadapi kenyataan itu, menurut Satjipto Rahardjo, cara-cara analisis yang murni dan formal sangat dirasakan kekurangannya. ${ }^{7}$ Hukum harus selalu hidup di masyarakat mengingat keberadaan hukum sangat berkaitan dengan keberadaan masyarakat itu sendiri, seperti dikemukakan oleh Celcius, "ubi societas, ibi ius". ${ }^{8}$

Dari penjelasan mengenai hubungan politik dan hukum, penjelasan Bayles tentang pola hubungan yang terbangun di antara hukum dan politik agaknya lebih menggambarkan gradasi hubungan yang lebih ideal. Melalui pola-pola hubungan yang diuraikannya, agaknya Bayles ingin menjelaskan posisi hukum yang suprematif tanpa mengesampingkan faktorfaktor non-hukum yang lain. Dalam kaitannya dengan keberadaan negara, penjelasan Bayles tersebut relevan dengan esensi institusi negara,

\footnotetext{
${ }^{6}$ Moh. Mahfud MD, Politik Hukum..., h. 9.

${ }^{7}$ Satjipto Rahardjo, Ilmu Hukum (Bandung: Citra Aditya Bhakti, 2000), h. 286

${ }^{8}$ F. Isjwara, Pengantar Ilmu Politik, (Bandung: Bina Cipta, 1974), h. 79.
}

yang oleh C.F.Strong diidentifikasi as distinct from all other forms of association, is the obedience of its members to the law. ${ }^{9}$

Mahfud MD mengatakan hubungan antara politik dan hukum terdapat tiga asumsi yang mendasarinya, yaitu (1) Hukum determinan (menentukan) atas politik, dalam arti hukum harus menjadi arah dan pengendali semua kegiatan politik. (2) Politik determinan atas hukum, dalam arti bahwa dalam kenyataannya, baik produk normatif maupun implementasi penegakan hukum itu, sangat dipengaruhi dan menjadi dipendent variable atas politik. (3) Politik dan hukum terjalin dalam hubungan yang saling bergantung, seperti bunyi adagium, "politik tanpa hukum menimbulkan kesewenangwenangan (anarkis), hukum tanpa politik akan jadi lumpuh. ${ }^{10}$

Berangkat dari studi mengenai hubungan antara politik dan hukum di atas kemudian lahir sebuah teori "politik hukum". Politik hukum adalah legal policy yang akan atau telah dilaksanakan secara nasional oleh pemerintah Indonesia yang meliputi:pertama, pembangunan yang berintikan pembuatan dan pembaruan terhadap materi-materi hukum agar dapat sesuai dengan kebutuhan. Kedua, pelaksanaan ketentuan hukum yang telah ada termasuk penegasan fungsi lembaga dan pembinaan para penegak hukum. ${ }^{11}$ Jadi politik hukum adalah bagaimana hukum akan atau seharusnya dibuat dan ditentukan arahnya dalam kondisi politik nasional serta bagaimana hukum difungsikan.

Teori politik hukum yang dirumuskan oleh Mahfud MD cenderung berkesimpulan bahwa yang terjadi Indonesia adalah politik determinan atas hukum. Situasi dan kebijakan politik yang sedang berlangsung sangat mempengaruhi sikap yang harus diambil oleh umat Islam, dan tentunya hal itu sangat berpengaruh pada produk-produk hukum yang dihasilkan.

Hubungan politik dengan hukum di dalam

${ }^{9}$ C.F.Strong, Modern Political Constitution, revised edition (London:Sidgwick and Jackson, 1952), h. 4.

${ }^{10}$ C.F.Strong, Modern Political..., h. xi-xii.

${ }^{11}$ Moh. Mahfud MD, Politik Hukum..., h. 9. 
studi mengenai hubungan antara politik dengan hukum terdapat asumsi yang mendasarinya. Pertama, hukum determinan terhadap politik dalam arti bahwa hukum harus menjadi arah dan pengendali semua kegiatan politik. Asumsi ini dipakai sebagi landasan das sollen (keinginan, keharusan dan cita). Kedua, politik determinan terhadap hukum dalam arti bahwa dalam kenyataannya baik produk normative maupun implementasi-penegakannya hukum itu sangat dipengaruhi dan menjadi dependent variable atas politik. Asumsi ini dipakai sebagai landasan das sein (kenyataan, realitas) dalam studi hukum empiris. Ketiga, politik dan hukum terjalin dalam hubungan interdependent atau saling tergantung yang dapat dipahami dari adugium, bahwa "politik tanpa hukum menimbulkan kesewenang-wenangan atau anarkis, hukum tanpa politik akan menjadi lumpuh". Mahfud MD mengatakan hukum dikonstruksikan secara akademis dengan menggunakan asumsi yang kedua, bahwa dalam realitasnya "politik determinan (menentukan) atas hukum". Jadi hubungan antara keduanya itu hukum dipandang sebagai dependent variable (variable pengaruh), politik diletakkan sebagai independent variable (variabel berpengaruh).

Pada tataran empiris, politik hukum telah digunakan oleh Mahfud MD dalam memahami relasi antara hukum dan politik. Mahfud MD menghadirkan sebuah pendekatan yang berbeda dalam memahami sebuah fenomena hukum, dalam hal ini berbeda dengan pendekatan klasik yang melihat hukum dari sisi yuridis normatif an sich, Mahfud MD melihat hukum dari sisi yuridis sosio politis, yang menghadirkan sistem politik sebagai variabel yang mempengaruhi rumusan dan pelaksanaan hukum. Berdasarkan hasil penelitiannya, Mahfud MD berkesimpulan bahwa suatu proses dan konfigurasi politik rezim tertentu akan signifikan pengaruhnya terhadap suatu produk hukum yang kemudian dilahirkannya. Negara yang konfigurasi politiknya demokratis, produk hukumnya berkarakter responsif atau populistik, sedangkan di negara yang konfigurasi politiknya otoriter, produk hukumnya berkarakter ortodoks atau konservatif atau elitis. ${ }^{12}$ Pernyataan tersebut dapat disajikan dalam gambar sebagai berikut :

Hasil yang kurang lebih sama diperoleh dari penelitian Benny K. Harman terhadap hubungan linier antara konfigurasi politik dan kekuasaan kehakiman. Menurutnya apabila dalam suatu negara diterapkan suatu konfigurasi politik yang demokratis, karakter kekuasaan kehakiman yang dihasilkan oleh konfigurasi politik semacam itu adalah karakter kekuasaan kehakiman yang independen atau otonom. Begitu pula apabila yang diterapkan konfigurasi politik otoriter atau totaliter, yang dihasilkannya adalah karakter kekuasaan kehakiman yang tidak otonom atau tidak bebas. ${ }^{13}$ Pernyataan tersebut dapat digambarkan seperti gambar di bawah ini:

Bila diperhatikan secara seksama, baik Mahfud MD maupun Harman menggunakan asumsi yang sama, yaitu ada keterkaitan antara hukum dan politik, meskipun objek penelitiannya berbeda. Mahfud MD lebih menekankan pada aspek keterkaitan antara konfigurasi politik dan karakter produk hukum, sedangkan Harman lebih menekankan pada aspek keterkaitan konfigurasi politik dan karakter kekuasaan kehakiman, apakah dia bersifat otonom atau tidak otonom. Dari hasil penelitiannya, kedua berpendapat bahwa konfigurasi politik sangat mempengaruhi karakter hukum dan karakter kekuasaan kehakiman.

Permasalahannya, apakah contoh di atas termasuk dalam penelitian hukum atau politik? Mahfud MD dalam bukunya secara jelas menyatakan bahwa model yang dia lakukan adalah penelitian hukum, bukan politik. Berdasarkan argumen bahwa politik hukum merupakan bagian dari ilmu hukum bukan ilmu politik. Ia menjelaskan bahwa, bila ilmu hukum diibaratkan sebagai pohon, filsafat merupakan akarnya, sedangkan politik merupakan batangnya yang kemudian melahirkan cabang-cabang berupa berbagai bidang hukum, seperti hukum perdata, hukum

\footnotetext{
${ }^{12}$ Moh. Mahfud MD, Politik Hukum..., h. 22

${ }^{13}$ Benny K. Harman, Konfigurasi Politik dan Kekuasaan Kehakiman di Indonesia, cet. 1, (Jakarta: Elsam, 1997)
} 
pidana, hukum tata negara, hukum administrasi negara dan sebagainya. ${ }^{14}$

\section{Negara-Agama dan Posisi Hukum Syariah}

Menurut Mahfud MD, secara yuridiskonstitusional negara Indonesia bukanlah negara agama dan bukan pula negara sekuler. Indonesia adalah religious nation state atau negara kebangsaan yang beragama. Indonesia adalah negara yang menjadikan ajaran agama sebagai dasar moral, sekaligus sebagai sumber hukum materiil dalam penyelenggaraan kehidupan berbangsa dan bernegara. Karena itu dengan jelas dikatakan bahwa salah satu dasar negara Indonesia adalah "Ketuhanan Yang Maha Esa". ${ }^{15}$

Masalah agama merupakan persoalan yang sejak dari awal Indonesia merdeka pada tahun 1945 menjadi perdebatan yang sengit diantara the founding fathers. Pada tanggal 22 Juni 1945 digelar sidang Badan Penyelidik Usaha-Usaha Persiapan Kemerdekaan Indonesia (BPUPKI) yang pertama untuk membahas dasar negara Indonesia kelak setelah merdeka. Pembahasan tersebut dilakukan oleh panitian sembilan yang beranggotakan Ir. Soekarno, Mohammad Hatta, A.A. Maramis, Abikoesno Tjokrosoejoso, Abdulkahar Muzakir, H.A. Salim, Achmad Subardjo, Wahid Hasjim, dan Muhammad Yamin. Panitia sembilan berhasil merumuskan dasar-dasar negara yang berisi lima sila yang kemudian disebut Pancasila, yaitu : (1) Ketuhanan dengan kewajiban menjalankan syariat Islam bagi pemeluk-pemeluknya; (2) Kemanusiaan yang adil dan beradab; (3) Persatuan Indonesia; (4) Kerakyatan yang dipimpin oleh hikmat kebijaksanaan dalam permusyawaratan perwakilan; (5) Keadilan sosial bagi seluruh rakyat Indonesia

Namun setelah Indonesia merdeka pada tanggal 17 Agustus 1945, BPUPKI kembali menggelar sidang kedua dimana salah satunya mensahkan rancangan konstitusi yang telah dibuat sebelumnya menjadi konstitusi resmi negara. Hal yang sangat mengejutkan pada

\footnotetext{
${ }^{14}$ Moh. Mahfud MD., Politik Hukum..., h. 8.

${ }^{15}$ Moh. Mahfud MD., Politik Hukum..., h. 8.
}

saat itu ialah dirubahnya isi poin pertama dasar negara yang berbunyi "Ketuhanan dengan kewajiban menjalankan syariat Islam bagi pemeluk-pemeluknya" dan digantikan dengan poin yang berbunyi "Ketuhanan Yang Maha Esa". Dalam catatan sejarah, perubahan tersebut dilakukan oleh Mohammad Hatta yang kemudian menjadi Waki Presiden Pertama Indonesia setelah mendengar usul dari A.A.Maramis (satu-satunya anggota panitia sembilan yang beragama kristen) setelah berkonsultasi dengan Teuku Muhammad Hassan, Kasman Singodimedjo dan Ki Bagus Hadikusumo ${ }^{16}$.

Latar belakang politis (political background) yang sering dikemukakan dalam berbagai tulisan atas perubahan bunyi sila pertama tersebut adalah adanya ancaman dari A.A.Maramis yang mewakili masyarakat Indonesia dari wilayah Timur dan beragama kristen untuk memisahkan diri dari Indonesia, jika poin pertama yang berbunyi "Ketuhanan dengan kewajiban menjalankan syariat Islam bagi pemeluk-pemeluknya" tidak dihapuskan atau diganti.

Hal itulah yang melatarbelakangi, mengapa hingga saat ini ${ }^{17}$ Indonesia tidak memiliki agama resmi negara, kendati di Indonesia kebebasan beragama di atur dalam konstitusinya (UUD 1945). Dalam pasal 29 UUD 1945 disebutkan: (1). Negara berdasarkan Ketuhanan Yang Maha Esa; (2). Negara menjamin kemerdekaan tiaptiap masyarakat untuk memeluk agamanya masing-masing dan untuk beribadah sesuai dengan agama dan kepercayaannya itu.

Namun dalam prakteknya, di Indonesia ummat Islam sebagai masyarakat mayoritas memiliki berbagai keistemewaan antara lain

\footnotetext{
${ }^{16}$ Piagam Jakarta, http://id.wikipedia.org/wiki/ Piagam_Jakarta, diakses tanggal 24 Pebruari 2015.

${ }^{17}$ Perjuangan untuk mengembalikan Piagam Jakarta dilakukan oleh beberapa kalangan, terutama setelah jatuhnya Presiden Soeharto (reformasi). Partai Politik yang konsisten mengangkat isue ini adalah Partai Bulan Bintang (PBB) yang diketuai Yusril Ihza Mahendra, seorang profesor undangundang perlembagaan pada Universitas Indonesia. Namun Partai ini tidak memiliki suara yang cukup untuk melakukan amandemen konstitusi, terlebih tidak didukung oleh partaipartai lainnya.
} 
dapat dilihat dalam berbagai indikasi berikut: Pertama, dalam menyelesaikan persoalanpersoalan tertentu di bidang hukum, masyarakat yang beragama Islam diberikan perlindungan hukum dan penyelesaian sesuai dengan hukum Islam. Hal ini seiring dengan adanya lembaga peradilan di Indonesia bernama Pengadilan Agama. Dalam pasal 49 ayat (1) Undang-Undang (UU) Nomor 3 tahun 2006 Tentang Peradilan Agama disebutkan bahwa Pengadilan Agama bertugas dan berwenang memeriksa, memutus, dan menyelesaikan perkara-perkara di tingkat pertama antara orang-orang yang beragama Islam di bidang: a) perkawinan; b) waris; c) wasiat; d) hibah; e) wakaf; f) zakat; g) infaq; h) shadaqah; dan i) ekonomi syari'ah. Apabila para pihak tidak berpuas dengan putusan yang dibuat oleh Pengadilan Agama, maka mereka dapat mengajukan gugatan (petition) kepada Pengadilan Tinggi Agama yang berada di setiap Ibukota Provinsi-provinsi yang ada di Indonesia. Di tingkat paling tinggi terdapat Mahkamah Agung yang memutuskan dan memeriksa perkara pada tingkat terakhir.

Kedua, dalam hal pelaksanaan dan pencatatan perkawinan hanya masyarakat yang beragama Islam yang memiliki pelayanan khas melalui Kantor Urusan Agama (KUA). KUA merupakan institusi yang khas dipersiapkan oleh pemerintah Indonesia untuk menangani pentadbiran pernikahan (perkawinan) bagi orang yang beragama Islam di Indonesia. KUA didirikan di setiap kecamatan yang ada di Indonesia. Sedangkan umat agama lain (selain Islam) mencatatkan perkawinannya di Kantor Catatan Sipil yang berada di setiap kabupaten ${ }^{18}$. Ketiga, Pemerintah Indonesia melalui Departemen Agama memiliki tugas melaksanakan dan mengurus seluruh hal yang berkaitan dengan ibadah Haji. Haji adalah ibadah wajib umat Islam Islam sebagaimana termaktub dalam rukun Islam. Ummat Islam di Indonesia difasilitasi

\footnotetext{
${ }^{18}$ Indonesia merupakan negara kesatuan (unity state) yang berbentuk republik yang terdiri dari wilayah-wilayah provinsi dimana setiap provinsi terbagi atas wilayah-wilayah kabupaten/kota yang kemudian wilayah tersebut terbagi-bagi lagi menjadi wilayah-wilayah bernama kecamatan. Pasal 18 UUD Republik Indonesia 1945 (konstitusi Indonsia).
}

dan diataur oleh negara dalam melaksanakan ibadah tersebut. Hal ini berbeda dengan umat agama lain, selain Islam yang tidak difasilitasi dalam menjalankan perjalanan ibadahnya, seperti ziarah ummat kristen ke Vatikan dan lain-lain.

Keempat, saat ini setelah diterapkan otonomi daerah, beberapa daerah membuat peraturan daerah (perda) yang mengatur tentang perilaku kehidupan seorang, sekaligus memberikan perlindugan kepada mereka. Sebagai contoh Perda Kabupaten Banjar No.4 tahun 2005 tentang Kewajiban Pandai Baca Tulis Al-Quran bagi siswa/siswi SD/MI sederajat dan Perda Kota Banjarmasin No.6 Tahun 2004 tentang larangan Minuman Keras (Miras) di Kota Banjarmasin. ${ }^{19}$ Kelima, Kebijakan pemerintah Indonesia untuk memberikan hari libur bersama pada hari-hari besar agama Islam, seperti libur pada saat Bulan Ramadhan yang dilaksanakan satu bulan penuh, serta libur untuk Idul Fitri yang dilaksanakan lebih dari satu minggu. Hal ini tidak didapati pada hari besar agama lain, seperti Natal, Nyepi dan lainnya. Libur pada hari-hari tersebut terbatas pada hari pelaksanaan hari raya-nya.

Keenam, Majelis Ulama Indonesia (MUI) yang berada mulai dari tingkat pusat, provinsi sampai ke tingkat kabupaten/kota. MUI memiliki wewenang untuk membuat fatwa. Fatwa MUI yang mengikat, bukan hanya untuk umat Islam, melainkan juga umat non-muslim adalah fatwa halal atau haram suatu produk makanan dan/atau minuman yang diproduksi di Indonesia. Fatwa tersebut merupakan syarat yang wajib dipenuhi bagi setiap perusahaan yang ingin menjual produknya di Indonesia. Fatwa MUI ini dimaksudkan untuk memberi proteksi kepada umat Islam agar mendapatkan makana dan/atau minuman yang halal di pasar Indonesia.

\footnotetext{
${ }^{19}$ M. Rifqinizamy, Kedudukan Peraturan Daerah (Perda) Syariah di Kalimantan Selatan dari Perspektif Hukum Tata Negara, disajikan dalam Seminar Serantau "Perkembangan Islam di Borneo" yang diselenggarakan oleh Universiti Tekhnologi Mara (UiTM) Malaysia, 27-28 Februari 2008
} 


\section{Politik Hukum Ekonomi Syariah}

Untuk melihat sejauhmana keberpihakan politik hukum nasional terhadap keberadaan ekonomi syariah di Indonesia, kita dapat melihatnya melalui dua aspek, yaitu aspek kelembagaan dan aspek substansi hukum yang tercermin dari lahirnya peraturan perundangundangan yang ada. Pada ranah kelembagaan, politik hukum nasional memberikan pengaturan yang menghadirkan kelembagaan yang memiliki otoritas dalam pengelolaan ekonomi syariah. Sebagai contoh, keberadaan Peradilan Agama sebagai institusi kekuasaan kehakiman yang diberikan kewenangan untuk menyelesaikan sengketa ekonomi syariah dalam yuridiksi absolutnya. Hal ini dapat dilihat dalam ketentuan Pasal 49 UU Nomor 3 Tahun 2006 tentang Perubahan Pertama UU Nomor 7 Tahun 1989 tentang Peradilan Agama.

Pada ranah kelembagaan pula, hadirnya Dewan Syariah Nasional (DSN) dan Badan Arbitrase Syariah (Basyarnas) adalah lompatan maju dalam politik hukum nasional. Kedua lembaga tersebut berada di bawah MUI. Dalam struktur ketatanegaraan, MUI bukanlah bagian dari organ kekuasaan resmi negara. MUI lebih tepat disebut sebagai badan hukum biasa. Ia sejajar dengan berbagai organisasi keagamaan lainnya.

Kehadiran DSN dan Basyarnas dalam struktur hukum nasional seiring dengan diberlakukannya UU Nomor 21 Tahun 2008 tentang Perbankan Syariah. Kehadiran UU tersebut menuntut hadirnya institusi penetapan legislasi dan pengawas fatwa di bidang ekonomi syariah yang dilakukan oleh DSN, serta institusi penyelesaian sengketa di luar peradilan (alterbative dispute resolution).

\section{DAFTAR PUSTAKA}

Bayles, Michael. Law and Politics, http:// www.bibliojuridica.org/libros/3/1014/14.pdf, diakes tanggal 16 Mei 2013.

Harman, Benny K., Konfigurasi Politik dan Kekuasaan Kehakiman di Indonesia, Cet. 1. Jakarta: Elsam, 1997
Kelembagaan Basayrnas dimaksudkan sebagai cara penyelesaian sengketa alternatif selain ke Peradilan Agama.

Pada aspek peraturan, kehadiran berbagai UU seperti UU No.21 Tahun 2008 tentang Perbankan Syariah, UU Nomor 19 Tahun 2008 tentang Surat Berharga Syariah, UU 23 Tahun 2011 tentang Pengelolaan Zakat, UU No.7Tahun 1989 sebagaimana diberbaharui dengan UU Nomor 3 Tahun 2006 dan UU Nomor 50 Tahun 2009 tentang Peradilan Agama, UU 41 Tahun 2004 tentang Wakaf dan berbagai ketentuan paraturan perundang-undangan lainnya.

Secara lebih spesifik, Fatwa DSN MUI yang sesungguhnya bukan bagian dari produk peraturan perundang-undangan nasional kita, juga dapat dikonversi menjadi dasar hukum tata kelola ekonomi syariah di Indonesia, setelah dilakukan otorisasi oleh Bank Indonesia melalui Peraturan Bank Indonesia sebagaimana diatur dalam UU Nomor 21 Tahun 2008 tentang Perbankan Syariah.

\section{Kesimpulan}

Politik hukum nasional menempatkan keberpihakan yang kuat pada legislasi hukum Islam, baik pada aspek kelembagaan, maupun substansi pengaturannya. Hal ini sekaligus mempertegas, bahwa keberadaan umat Islam sebagai mayoritas penduduk Indonesia diberikan perlindungan hukum yang baik oleh negara. Pada sisi yang lain, perdebatan perlu tidaknya Islam diletakkan sebagai dasar negara, sekaligus menjadikan hukum Islam sebagai hukum positif tidak perlu dilakukan,lantaran secara substansial pelbagai hukum Islam dapat dijadikan bagian dari hukum positif nasional kita.

Isjwara, F. Pengantar Ilmu Politik. Bandung: Bina Cipta, 1974

Kelsen, Hans. Teori Umum tentang Hukum dan Negara (General Theory of Law and State). Terjemahan oleh Raisul Muttaqien. Bandung: Nusa Media, 2006 
46 I de Jure, Jurnal Syariah dan Hukum, Volume 7 Nomor 1, Juni 2015, hlm. 39-46

MD, Moh. Mahfud. Politik Hukum di Indonesia. Jakarta: Rajawali Press, 2010

Piagam Jakarta, http://id.wikipedia.org/wiki/ Piagam_Jakarta, diakses tanggal 24 Pebruari 2015.

Rifqinizamy, M. Kedudukan Peraturan Daerah (Perda) Syariah di Kalimantan Selatan dari Perspektif Hukum Tata Negara. Makalah disajikan dalam Seminar Serantau "Perkembangan Islam di
Borneo", Universiti Tekhnologi Mara (UiTM) Malaysia, 27-28 Pebruari 2008

Rahardjo, Satjipto. Ilmu Hukum. Bandung: Citra Aditya Bhakti, 2000

Strong, C.F. Modern Political Constitution, Revised edition. London:Sidgwick and Jackson, 1952

Syaukani, Imam dan A. Ahsin Thohari, Dasar-Dasar Politik Hukum. Jakarta: Rajawali Pres, 2012 